\title{
Article \\ Influence of Small Quantities of Water on the Physical Properties of Alkylammonium Nitrate Ionic Liquids
}

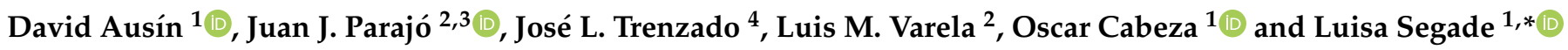 \\ 1 Departamento de Física, Facultade de Ciencias, Campus da Zapateira, Universidade da Coruña, \\ 15071 A Coruña, Spain; david.ausin.neira@udc.es (D.A.); oscar.cabeza@udc.es (O.C.) \\ 2 Grupo de Nanomateriais, Fotónica e Materia Branda, Departamento de Física de Partículas y Departamento \\ de Física Aplicada, Universidade de Santiago de Compostela, Campus Vida s/n, \\ 15782 Santiago de Compostela, Spain; juanjose.parajo@usc.es (J.J.P.); luismiguel.varela@usc.es (L.M.V.) \\ 3 Departamento de Química e Bioquímica, CIQUP-Centro de Investigaçao em Química da Universidade do \\ Porto, Universidade do Porto, P-4169-007 Porto, Portugal \\ 4 Departamento de Física, Universidad de Las Palmas de Gran Canaria, 35017 Las Palmas Gran Canaria, Spain, \\ jose.trenzado@ulpgc.es \\ * Correspondence: luisa.segade@udc.es; Tel.: +34-981167000
}

check for

updates

Citation: Ausín, D.; Parajó, J.J.; Trenzado, J.L.; Varela, L.M.; Cabeza, O.; Segade, L. Influence of Small Quantities of Water on the Physical Properties of Alkylammonium Nitrate Ionic Liquids. Int. J. Mol. Sci. 2021, 22, 7334. https://doi.org/ $10.3390 /$ ijms 22147334

Academic Editors: José S. Urieta and Ana M. Mainar

Received: 8 June 2021

Accepted: 2 July 2021

Published: 8 July 2021

Publisher's Note: MDPI stays neutral with regard to jurisdictional claims in published maps and institutional affiliations.

Copyright: (c) 2021 by the authors. Licensee MDPI, Basel, Switzerland. This article is an open access article distributed under the terms and conditions of the Creative Commons Attribution (CC BY) license (https:/ / creativecommons.org/licenses/by/ $4.0 /)$.

\begin{abstract}
This paper presents a comprehensive study of two alkylammonium nitrate ionic liquids. As part of this family of materials, mainly ethylammonium nitrate (EAN) and also propylammonium nitrate (PAN) have attracted a great deal of attention during the last decades due to their potential applications in many fields. Although there have been numerous publications focused on the measurement of their physical properties, a great dispersion can be observed in the results obtained for the same magnitude. One of the critical points to be taken into account in their physical characterization is their water content. Thus, the main objective of this work was to determine the degree of influence of the presence of small quantities of water in EAN and PAN on the measurement of density, viscosity, electrical conductivity, refractive index and surface tension. For this purpose, the first three properties were determined in samples of EAN and PAN with water contents below $30,000 \mathrm{ppm}$ in a wide range of temperatures, between 5 and $95^{\circ} \mathrm{C}$, while the last two were obtained at $25^{\circ} \mathrm{C}$. As a result of this study, it has been concluded that the presence of water is critical in those physical properties that involve mass or charge transport processes, resulting in the finding that the absolute value of the average percentage change in both viscosity and electrical conductivity is above $40 \%$. Meanwhile, refractive index $(\leq 0.3 \%)$, density $(\leq 0.5 \%)$ and surface tension $(\leq 2 \%)$ present much less significant changes.
\end{abstract}

Keywords: ionic liquid; ethylammonium nitrate; propylammonium nitrate; water-free; density; viscosity; electrical conductivity; refractive index; surface tension

\section{Introduction}

During the last decades, the study of ionic liquids (ILs) has aroused enormous interest in the scientific community because of their extraordinary physical properties and versatility, which have made them worthy of becoming a true field of research [1]. The main feature that made them attractive is that they can be tailor-made by combining the cations and anions of which they can be composed, obtaining a great variety of ILs with very different properties and applications.

After a couple of decades of extensive development in the study of the potential uses of ILs, their applications are now a reality in many branches of science and industry. Thus, their uses have been demonstrated in a wide range of areas of analytical chemistry [2], organic chemistry [3,4], electrochemical conversion and energy storage [5], biosensing technology [6], pharmaceutical and biomedical industry $[7,8]$ or recovery of industrial solvents $[9,10]$, to name but a few. In this context, the characterization of these materi- 
als through experimental, theoretical or computational methods plays a decisive role to promote their industrial applications [11].

In this work, we continue with the experimental study of ILs to which our groups have been devoted in the past years [12-14], and specifically, we focus on one of our lines of work dedicated to protic ionic liquids (PILs) $[15,16]$, the usefulness of which has been widely tested. Within this class of materials, two representatives of the family of alkylammonium nitrates, ethylammonium nitrate (EAN) and propylammonium nitrate (PAN), have attracted great attention as a result of their multiple applications. Many examples of them can be found in fields as diverse as electrodeposition, electrochemical exfoliation, liquid-liquid extraction, organic or inorganic synthesis, biocatalysis, lubrication or biological medium solvents, among others $[17,18]$. More recent works have already explored their utility as components of smart materials [19], in hydrogen sorption processes [20], in thermoelectric generator devices [21] or in studies on the structural stability and aggregation state of proteins [22]. In general, EAN and PAN have been the subject of many studies, reported in more than 700 bibliographic references (SciFindern database), as can be seen in Figure 1. A large part of these references has been devoted to exploring the uses of these compounds, while approximately half of them have focused on the determination of their physicochemical properties.

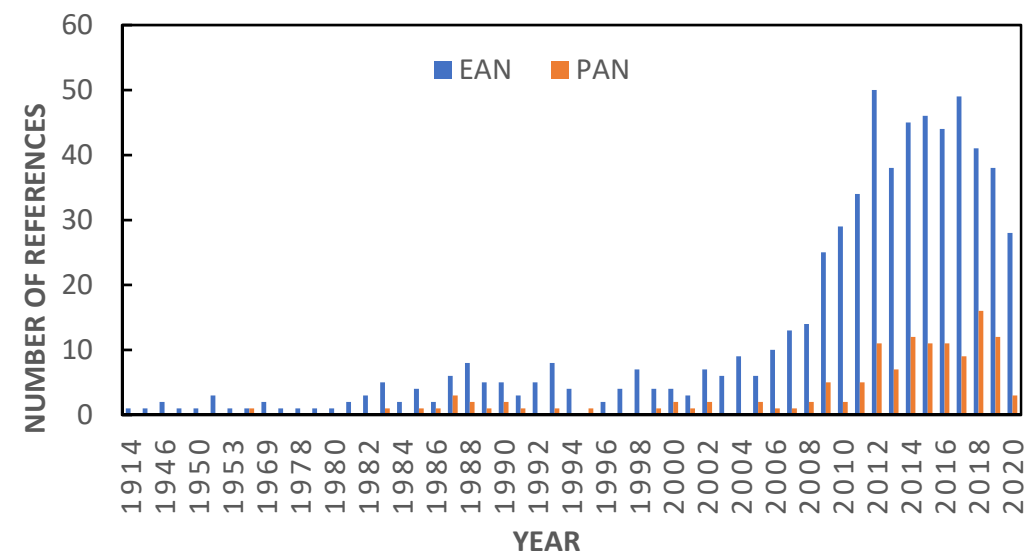

Figure 1. Increase in the number of bibliographic references related to EAN and PAN from their discovery to nowadays (SciFinder ${ }^{\mathrm{n}}$ database).

Considering that a thorough and accurate characterization of these materials has a direct impact on the knowledge of their structure and in the design of their potential applications, we have performed an exhaustive compilation of some of the most relevant physical properties. Thus, we have reviewed the state of the art of density, viscosity, electrical conductivity, refractive index and surface tension for EAN and PAN at different temperatures [23-89].

These properties enable us to anticipate the suitability of an IL in some applications. For instance, density and refractive index are two remarkably interesting parameters because, besides being useful to identify a substance, they allow obtaining other information such as ionic conductivities or electronic polarizabilities, respectively. Viscosity could be related to extraction processes, either facilitating dispersion (low viscosity) or by avoiding losses (high viscosity) [2]. In the case of batteries or electrochemical sensing systems, it is essential information to know thermal stability, electrochemical stability, electrical conductivity and viscosity [5]. Other studies that have analyzed the ability of certain ILs to act as surfactants have made use of the information provided by surface tension data, with the aim of developing drug delivery systems [8]. In all cases, it must be taken into account that the properties tend to depend on temperature, especially those related to mass or charge transport, which could limit their applications, it being necessary to have studies that establish this dependence. 
The aforementioned highlights the fact that, in order to properly design a process, the systematic and precise measurement of physicochemical properties is of the utmost importance. Despite this, we have found that the published results for a given property at the same temperature vary very significantly. According to all the data gathered in the literature, it could be assumed that water absorption from the atmosphere is one of the main reasons for the dispersion observed for a given property and temperature, since the two ILs studied here are hygroscopic substances, as are many ILs [90]. As a representative case, previously published densities $(\rho)$ of EAN measured at $25{ }^{\circ} \mathrm{C}$ are presented in Figure 2, along with the experimental densities studied here. In this figure, the property as a function of the water content $(\mathrm{w})$ accurately reported in the papers is represented using solid symbols, and with open ones if it was not.

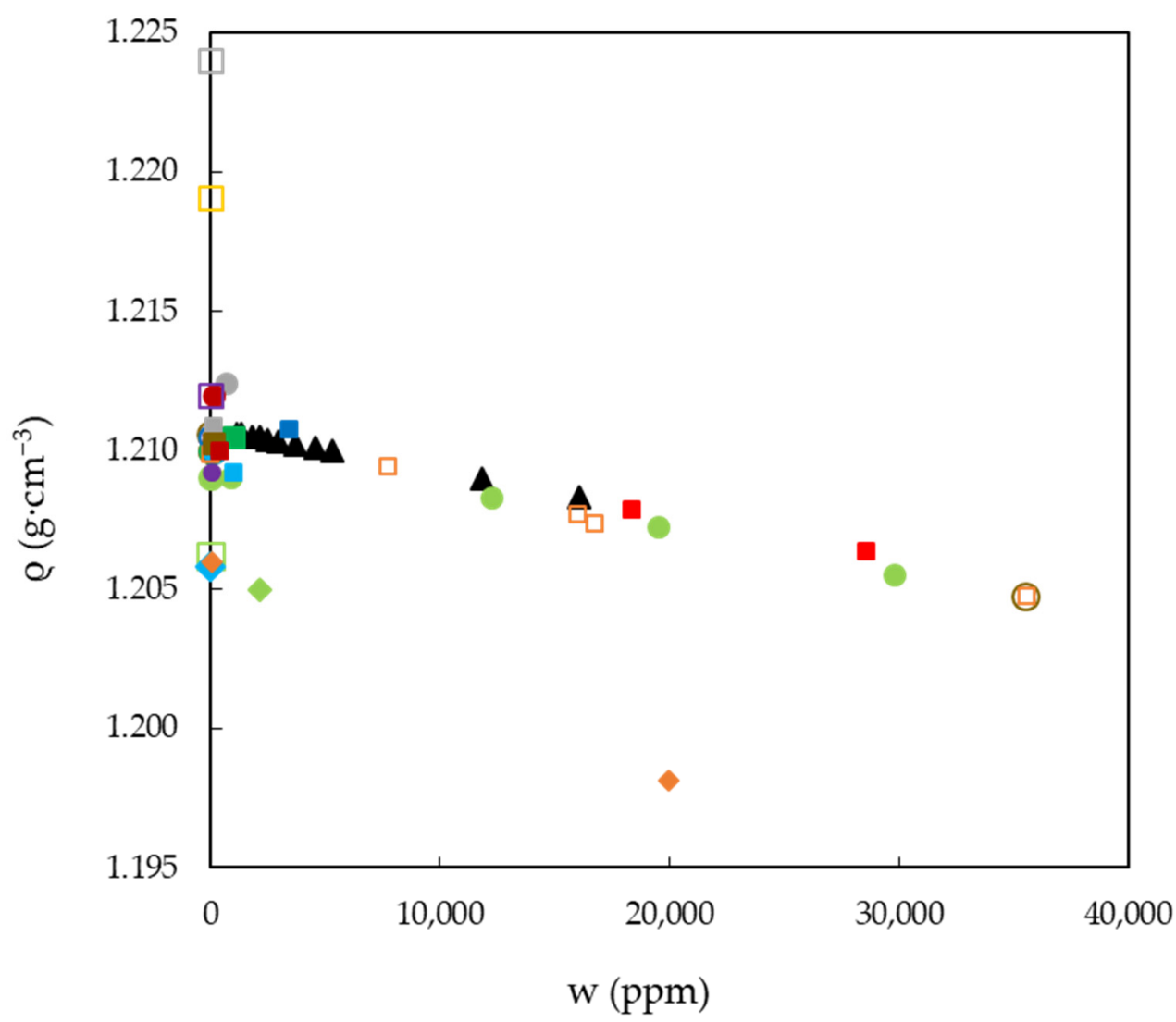

Figure 2. Experimental and published densities, $\rho$, of EAN as a function of the water content, $w$, at $25^{\circ} \mathrm{C}$. Symbols: present work (black solid triangles) and a compilation of those published data with an accurate measure of water content (solid) or not (open): [15] (red squares), [23] (green dots), [24] (yellow dots), [27] (orange dots), [28] (cyan dots), [29] (red dots), [32] (pink dots), [36] (grey dots), [41] (dark green dots), [46] (brown dots), [48] (blue dots), [52] (dark red dots), [58] (purple dots), [60] (green squares), [65] (yellow squares), [67] (orange squares), [70] (cyan squares), [71] (pink squares), [75] (grey squares), [76] (dark green squares), [77] (brown squares), [81] (blue squares), [82] (dark red squares), [85] (purple squares), [86] (green rhombs), [87] (cyan rhombs) and [89] (orange rhombs).

In view of the results, it seems critical to control and determine the water content if an accurate characterization is to be made. For this reason, in this work we have proposed as an objective to study systematically the influence of the content of small quantities of water (from about 300 to 30,000 ppm) in EAN and PAN on the measurement of density, viscosity and electrical conductivity from 5 to $95{ }^{\circ} \mathrm{C}$, and the refractive index and surface tension at $25^{\circ} \mathrm{C}$. To our knowledge, this comprehensive study of EAN and PAN has not been carried out over such a wide temperature range with a strict control of water content. 


\section{Results}

The characterization of EAN and PAN involves the measurement of physical properties covering a wide range of temperatures, between 5 and $95{ }^{\circ} \mathrm{C}$, when possible. This was the case for density, viscosity and electrical conductivity, which were measured every $5{ }^{\circ} \mathrm{C}$ for the first two and $10^{\circ} \mathrm{C}$ for the latter. Thus, Figure $3 a$,b shows the results obtained for the density of EAN and PAN as a function of the water content, respectively. In the same way, Figure $4 a, b$ and Figure $5 a, b$ display the experimental results of viscosity (on a semi logarithmic scale) and electrical conductivity. Finally, the refractive index and surface tension at $25^{\circ} \mathrm{C}$ of both LIs are plotted in Figure 6 . As can be seen, all the physical properties studied depend linearly on the composition in the concentration range studied, with the exception of the refractive index of EAN and the viscosity of PAN, whose relationship is better fitted through a polynomial of degree 2 .

All the experimental results obtained are shown in Tables S1-S5 in the Supporting Materials section. In all cases, the data were fitted to an equation of the type:

$$
\mathrm{Q}=\mathrm{Q}_{\mathrm{IL}}+\sum_{\mathrm{i}=1}^{\mathrm{N}} \mathrm{A}_{\mathrm{i}} \mathrm{w}^{\mathrm{i}}
$$

where $Q$ is the property studied $\left(\rho, \eta, \kappa, n_{D}\right.$ or $\left.\sigma\right)$ of the IL at a given temperature and content in water $(\mathrm{w}), \mathrm{Q}_{\mathrm{IL}}$ is the corresponding property of the IL without any water content $\left(\rho_{\mathrm{IL}}, \eta_{\mathrm{IL}}, \mathrm{K}_{\mathrm{IL}}, \mathrm{n}_{\mathrm{D}, \mathrm{IL}}\right.$ or $\left.\sigma_{\mathrm{IL}}\right)$ and $\mathrm{Q}_{\mathrm{IL}}$ and $\mathrm{A}_{\mathrm{i}}$ are fitting parameters. All the best values for the fitting parameters, $\mathrm{Q}_{\mathrm{IL}}$ and $\mathrm{A}_{\mathrm{i}}$, together with the coefficient of determinations, are shown in Tables $1-4$.

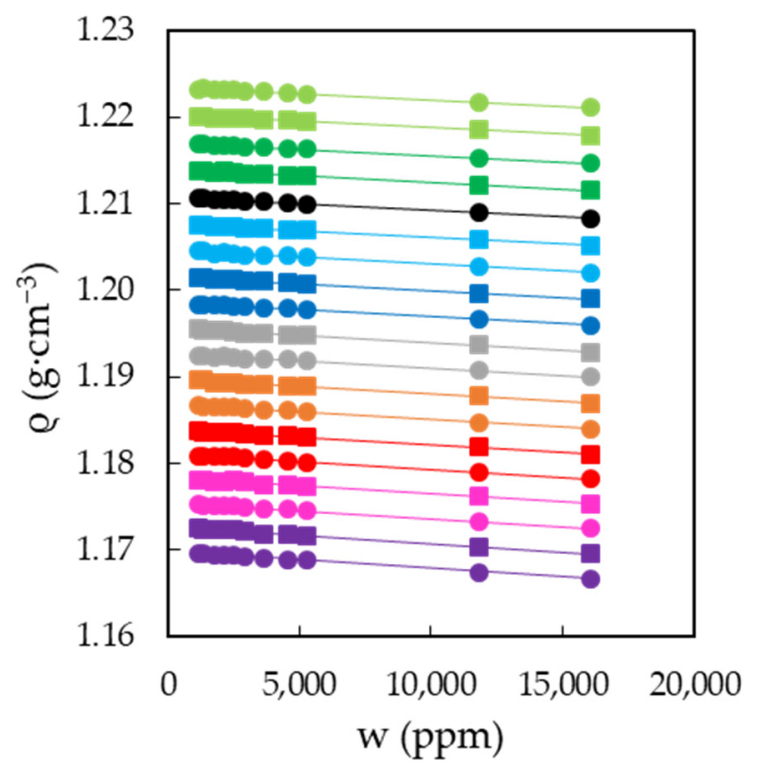

(a)

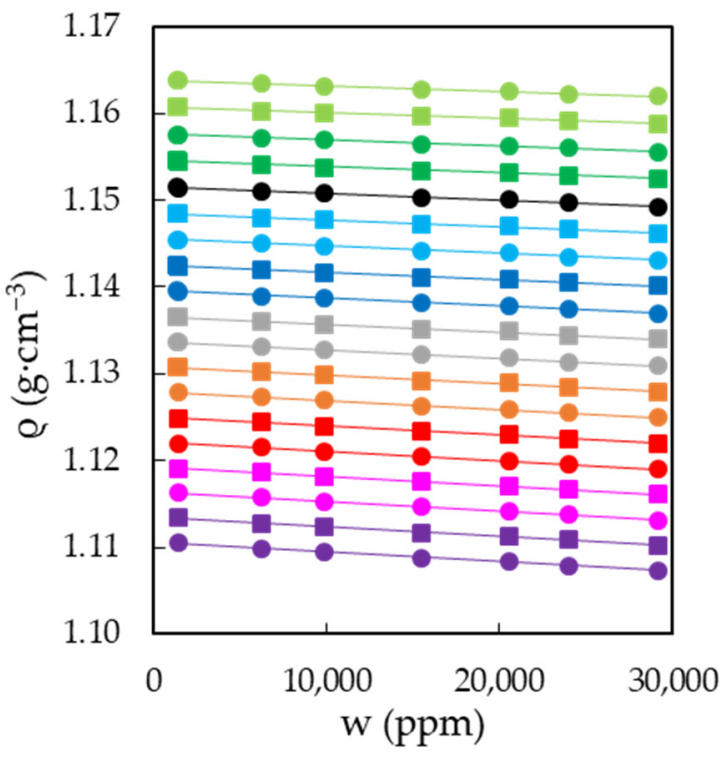

(b)

Figure 3. Densities, $\rho$, of EAN (a) and PAN (b) as a function of the water content, $w$, for the temperatures studied: 5 (green dots), 10 (green squares), 15 (dark green dots), 20 (dark green squares), 25 (black dots), 30 (cyan squares), 35 (cyan dots), 40 (blue squares), 45 (blue dots), 50 (grey squares), 55 (grey dots), 60 (orange squares), 65 (orange dots), 70 (red squares), 75 (red dots), 80 (pink squares), 85 (pink dots), 90 (purple squares) and $95{ }^{\circ} \mathrm{C}$ (purple dots). Solid lines were obtained from Equation (1). 


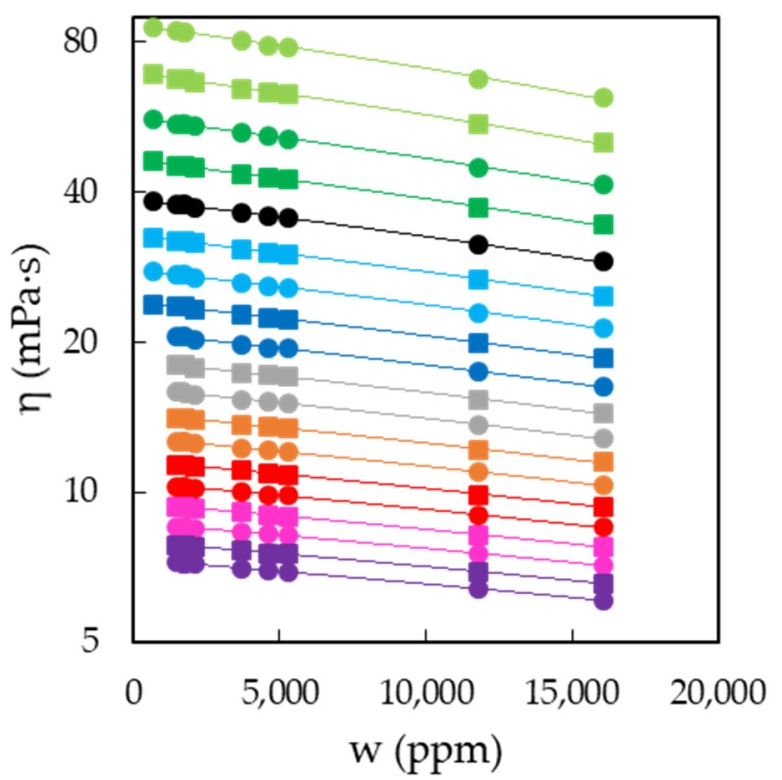

(a)

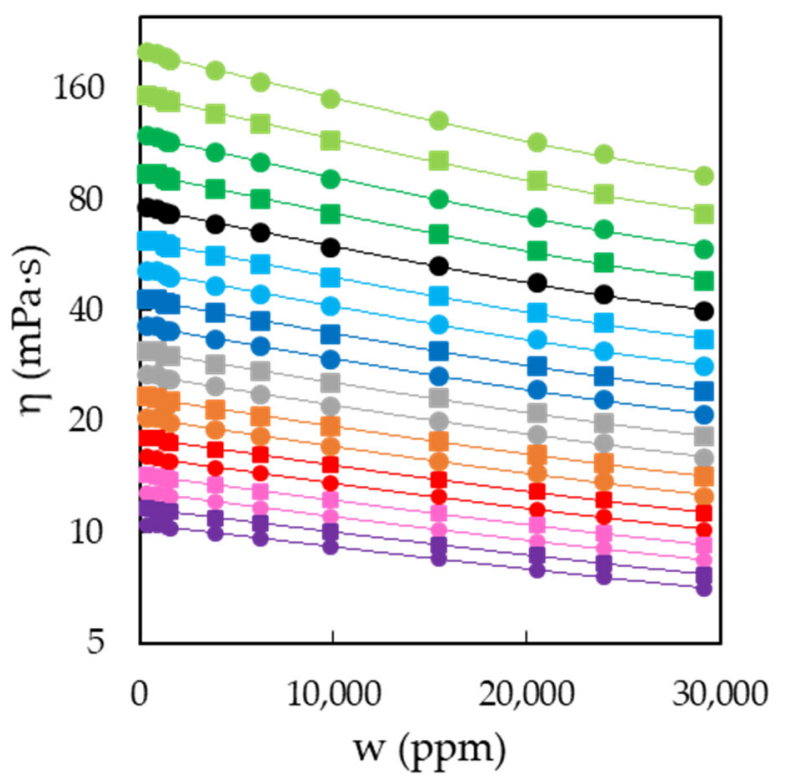

(b)

Figure 4. Viscosities, $\eta$, of EAN (a) and PAN (b) as a function of the water content, $w$, on a semi logarithmic scale for the temperatures studied: 5 (green dots), 10 (green squares), 15 (dark green dots), 20 (dark green squares), 25 (black dots), 30 (cyan squares), 35 (cyan dots), 40 (blue squares), 45 (blue dots), 50 (grey squares), 55 (grey dots), 60 (orange squares), 65 (orange dots), 70 (red squares), 75 (red dots), 80 (pink squares), 85 (pink dots), 90 (purple squares) and $95{ }^{\circ} \mathrm{C}$ (purple dots). Solid lines were obtained from Equation (1).

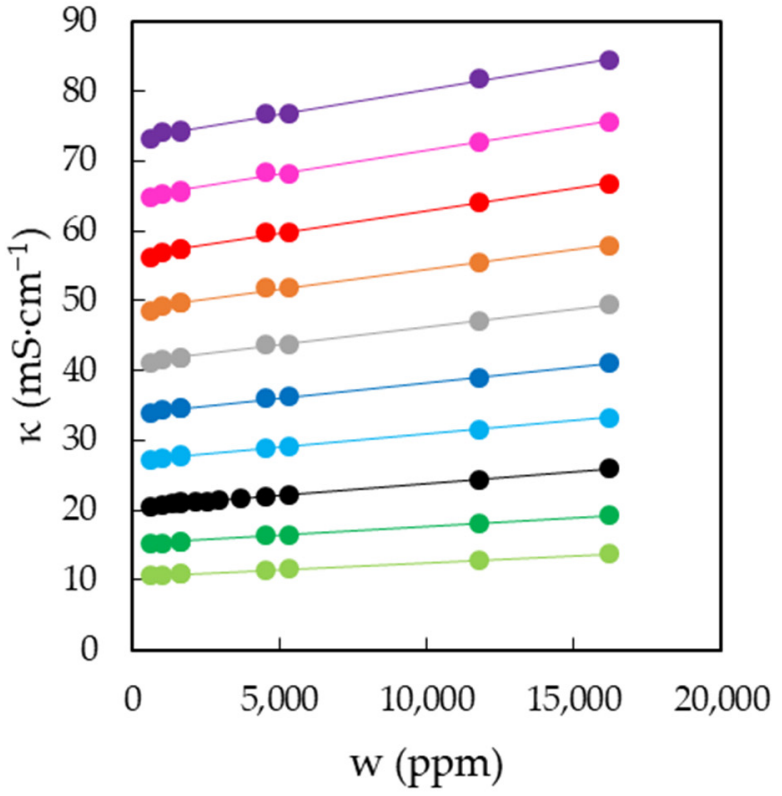

(a)

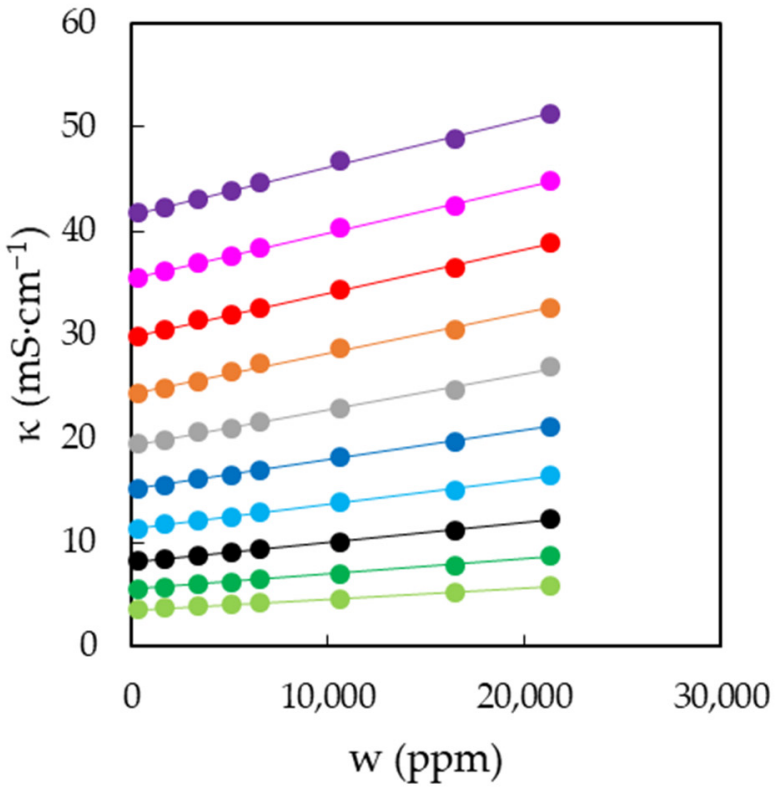

(b)

Figure 5. Electrical conductivities, $k$, of EAN (a) and PAN (b) as a function of the water content, w, for the temperatures studied: 5 (green dots), 15 (dark green dots), 25 (black dots), 35 (cyan dots), 45 (blue dots), 55 (grey dots), 65 (orange dots), 75 (red dots), 85 (pink dots) and $95^{\circ} \mathrm{C}$ (purple dots). Solid lines were obtained from Equation (1). 


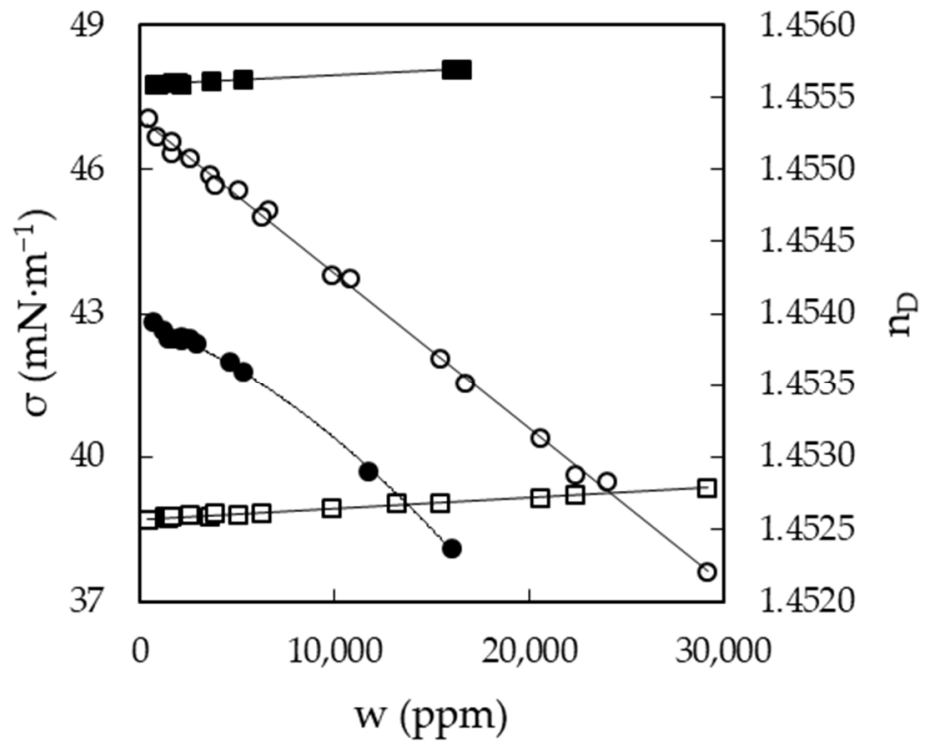

Figure 6. Refractive index, $\mathrm{n}_{\mathrm{D}}$ (dots), and surface tension, $\sigma$ (squares), of EAN (solid symbols) and PAN (open symbols) as a function of the water content, $\mathrm{w}$, at $25^{\circ} \mathrm{C}$. Solid lines were obtained from Equation (1).

Table 1. Fitting Equation (1) to density data $\left(\mathrm{g} \cdot \mathrm{cm}^{-3}\right)$ of EAN and PAN as a function of water content (ppm): parameters and coefficient of determination $\mathrm{R}^{2}$.

\begin{tabular}{ccccccc}
\hline \multicolumn{3}{c}{ EAN } & & \multicolumn{3}{c}{ PAN } \\
\hline $\mathbf{T ~}\left({ }^{\circ} \mathbf{C}\right)$ & $\boldsymbol{\rho}_{\text {IL }}$ & $\left.\mathbf{A}_{\mathbf{1}} \mathbf{( 1 0}^{\mathbf{7}}\right)$ & $\mathbf{R}^{\mathbf{2}}$ & $\boldsymbol{\rho}_{\text {IL }}$ & $\left.\mathbf{A}_{\mathbf{1}} \mathbf{( 1 0}^{\mathbf{7}}\right)$ & $\mathbf{R}^{\mathbf{2}}$ \\
\hline 5 & 1.2234 & -1.4448 & 0.9963 & 1.1639 & -0.66515 & 0.9941 \\
10 & 1.2202 & -1.4610 & 0.9971 & 1.1608 & -0.67382 & 0.9941 \\
15 & 1.2171 & -1.4745 & 0.9988 & 1.1577 & -0.70588 & 0.9958 \\
20 & 1.2140 & -1.5136 & 0.9939 & 1.1546 & -0.73063 & 0.9913 \\
25 & 1.2108 & -1.5354 & 0.9989 & 1.1516 & -0.76511 & 0.9945 \\
30 & 1.2077 & -1.5516 & 0.9978 & 1.1485 & -0.79664 & 0.9938 \\
35 & 1.2046 & -1.5800 & 0.9934 & 1.1456 & -0.83059 & 0.9926 \\
40 & 1.2016 & -1.6151 & 0.9988 & 1.1425 & -0.83760 & 0.9920 \\
45 & 1.1986 & -1.6151 & 0.9988 & 1.1396 & -0.89210 & 0.9908 \\
50 & 1.1956 & -1.6805 & 0.9977 & 1.1366 & -0.90778 & 0.9920 \\
55 & 1.1927 & -1.6700 & 0.9944 & 1.1337 & -0.96657 & 0.9944 \\
60 & 1.1898 & -1.6959 & 0.9969 & 1.1309 & -1.0122 & 0.9956 \\
65 & 1.1869 & -1.7551 & 0.9947 & 1.1279 & -1.0033 & 0.9986 \\
70 & 1.1840 & -1.7654 & 0.9913 & 1.1250 & -1.0411 & 0.9980 \\
75 & 1.1812 & -1.8331 & 0.9907 & 1.1222 & -1.0732 & 0.9995 \\
80 & 1.1783 & -1.8467 & 0.9922 & 1.1193 & -1.0732 & 0.9995 \\
85 & 1.1755 & -1.8688 & 0.9945 & 1.1164 & -1.1194 & 0.9981 \\
90 & 1.1727 & -1.9341 & 0.9969 & 1.1136 & -1.1428 & 0.9953 \\
95 & 1.1699 & -1.9799 & 0.9954 & 1.1106 & -1.1107 & 0.9927 \\
\hline
\end{tabular}


Table 2. Fitting Equation (1) to viscosity data (mPa.s) of EAN and PAN as a function of water content (ppm): parameters of Equation (1) and coefficient of determination $\mathrm{R}^{2}$.

\begin{tabular}{cccccccc}
\hline \multicolumn{3}{c}{ EAN } & \multicolumn{3}{c}{ PAN } \\
\hline $\mathbf{T ~}\left({ }^{\circ} \mathbf{C}\right)$ & $\boldsymbol{\eta}_{\mathbf{I L}}$ & $\mathbf{A}_{\mathbf{1}} \mathbf{( 1 0}^{\mathbf{4}} \mathbf{)}$ & $\mathbf{R}^{\mathbf{2}}$ & $\boldsymbol{\eta}_{\mathbf{I L}}$ & $\mathbf{A}_{\mathbf{1}} \mathbf{( 1 \mathbf { 1 0 } ^ { \mathbf { 4 } } )}$ & $\mathbf{A}_{\mathbf{2}} \mathbf{( 1 0 ^ { \mathbf { 9 } } )}$ & $\mathbf{R}^{\mathbf{2}}$ \\
\hline 5 & 86.5 & -15.60 & 0.9981 & 201.6 & -57.29 & 70.74 & 0.9990 \\
10 & 69.3 & -12.10 & 0.9983 & 153.7 & -41.82 & 50.26 & 0.9990 \\
15 & 56.3 & -9.517 & 0.9983 & 119.7 & -31.40 & 37.31 & 0.9989 \\
20 & 46.3 & -7.504 & 0.9984 & 94.8 & -23.98 & 28.02 & 0.9989 \\
25 & 38.7 & -6.084 & 0.9982 & 76.3 & -18.51 & 21.00 & 0.9988 \\
30 & 32.7 & -4.960 & 0.9989 & 62.3 & -14.56 & 16.29 & 0.9988 \\
35 & 27.9 & -4.125 & 0.9985 & 51.6 & -11.64 & 12.83 & 0.9987 \\
40 & 24.05 & -3.439 & 0.9987 & 43.2 & -9.434 & 10.30 & 0.9984 \\
45 & 20.92 & -2.901 & 0.9987 & 36.5 & -7.642 & 8.041 & 0.9987 \\
50 & 18.33 & -2.468 & 0.9987 & 31.2 & -6.293 & 6.465 & 0.9986 \\
55 & 16.19 & -2.120 & 0.9989 & 26.9 & -5.220 & 5.206 & 0.9983 \\
60 & 14.40 & -1.832 & 0.9989 & 23.39 & -4.362 & 4.224 & 0.9982 \\
65 & 12.88 & -1.600 & 0.9989 & 20.56 & -3.748 & 3.623 & 0.9989 \\
70 & 11.59 & -1.405 & 0.9990 & 18.15 & -3.191 & 2.991 & 0.9991 \\
75 & 10.48 & -1.239 & 0.9988 & 16.11 & -2.722 & 2.455 & 0.9993 \\
80 & 9.53 & -1.094 & 0.9987 & 14.40 & -2.340 & 2.026 & 0.9995 \\
85 & 8.69 & -0.9741 & 0.9987 & 12.93 & -2.021 & 1.673 & 0.9996 \\
90 & 7.97 & -0.8775 & 0.9989 & 11.68 & -1.764 & 1.419 & 0.9998 \\
95 & 7.34 & -0.7932 & 0.9989 & 10.59 & -1.534 & 1.157 & 0.9999 \\
\hline
\end{tabular}

Table 3. Fitting Equation (1) to electrical conductivity data $\left(\mathrm{mS} \cdot \mathrm{cm}^{-1}\right)$ of EAN and PAN as a function of water content (ppm): parameters and coefficient of determination $\mathrm{R}^{2}$.

\begin{tabular}{ccccccc}
\hline \multicolumn{3}{c}{ EAN } & \multicolumn{3}{c}{ PAN } \\
\hline $\mathbf{T}\left({ }^{\circ} \mathbf{C}\right)$ & $\mathbf{K}_{\mathbf{I L}}$ & $\left.\mathbf{A}_{\mathbf{1}} \mathbf{( 1 0}^{\mathbf{4}}\right)$ & $\mathbf{R}^{\mathbf{2}}$ & $\mathbf{K}_{\mathbf{I L}}$ & $\left.\mathbf{A}_{\mathbf{1}} \mathbf{( 1 0}^{\mathbf{4}}\right)$ & $\mathbf{R}^{\mathbf{2}}$ \\
\hline 5 & 10.55 & 1.989 & 0.9991 & 3.50 & 1.053 & 0.9982 \\
15 & 15.10 & 2.566 & 0.9990 & 5.52 & 1.451 & 0.9987 \\
25 & 20.4 & 3.436 & 0.9978 & 8.12 & 1.891 & 0.9986 \\
35 & 27.1 & 3.849 & 0.9982 & 11.34 & 2.364 & 0.9984 \\
45 & 33.9 & 4.469 & 0.9980 & 15.11 & 2.831 & 0.9990 \\
55 & 41.1 & 5.141 & 0.9968 & 19.37 & 3.450 & 0.9954 \\
65 & 48.7 & 5.780 & 0.9911 & 24.4 & 3.875 & 0.9927 \\
75 & 56.3 & 6.504 & 0.9951 & 29.9 & 4.185 & 0.9984 \\
85 & 64.7 & 6.795 & 0.9936 & 35.5 & 4.361 & 0.9981 \\
95 & 73.2 & 7.087 & 0.9942 & 41.6 & 4.548 & 0.9974 \\
\hline
\end{tabular}

Table 4. Fitting Equation (1) to refractive index and surface tension $\left(\mathrm{mN} \cdot \mathrm{m}^{-1}\right)$ data at $25^{\circ} \mathrm{C}$ of EAN and PAN as a function of water content (ppm): parameters and coefficient of determination $\mathrm{R}^{2}$.

\begin{tabular}{|c|c|c|c|c|c|c|c|}
\hline \multirow[b]{2}{*}{ Property } & \multicolumn{4}{|c|}{ EAN } & \multicolumn{3}{|c|}{ PAN } \\
\hline & $\mathrm{Q}_{\mathrm{IL}}$ & $\mathbf{A}_{1}$ & $\mathbf{A}_{2}$ & $R^{2}$ & $\mathrm{Q}_{\mathrm{IL}}$ & $\mathbf{A}_{1}$ & $\mathbf{R}^{2}$ \\
\hline$\frac{\mathrm{n}_{\mathrm{D}}}{\sigma\left(\mathrm{mN} \cdot \mathrm{m}^{-1}\right)}$ & $\begin{array}{c}1.45395 \\
4775\end{array}$ & $\begin{array}{c}-5.14135 \times 10^{-8} \\
2.008 \times 10^{-5}\end{array}$ & $-3.00678 \times 10^{-12}$ & $\begin{array}{l}0.9979 \\
0.9932\end{array}$ & $\begin{array}{c}1.45536 \\
38.72\end{array}$ & $\begin{array}{c}-1.08059 \times 10^{-7} \\
2.201 \times 10^{-5}\end{array}$ & $\begin{array}{l}0.9980 \\
0.9929\end{array}$ \\
\hline
\end{tabular}

\section{Discussion}

\subsection{Experimental Measurements as a Function of Water Content}

Analyzing the results obtained from the perspective of the influence of a low water content on the physical characterization of EAN and PAN, it can be clearly observed that not all properties are equally affected. Thus, the quantities most significantly modified by the presence of water are those of transport. The percentage change in viscosity averaged 
over all temperatures between water-free content $\left(\eta_{\mathrm{IL}}\right)$ and 30,000 ppm reaches $-39 \%$ and $-42 \%$ for EAN and PAN, respectively. Meanwhile, in the case of electrical conductivity, the corresponding percentage change is even greater, representing 43 and $56 \%$, respectively. At the other extreme, we find refractive index $(-0.11 \%$ and $-0.22 \%$, respectively), density $(-0.42 \%$ and $-0.22 \%)$ and surface tension $(1.3 \%$ and $1.7 \%)$.

As can be deduced from the data obtained, the presence of small quantities of water generates a considerable increase in both the fluidity of the liquid and the mobility of the charge. Although from a volumetric and surface point of view the liquids do not undergo such a marked change, it can be sufficiently significant when a characterization of the liquid structure is pursued.

\subsection{Experimental Measurements as a Function of Temperature}

From the fitting parameter $Q_{I L}$ of each property at each temperature, which corresponds to the values of the properties at water content $w=0$, in Figures 7 and 8 we have plotted the densities, viscosities and electrical conductivities of EAN and PAN as a function of temperature.

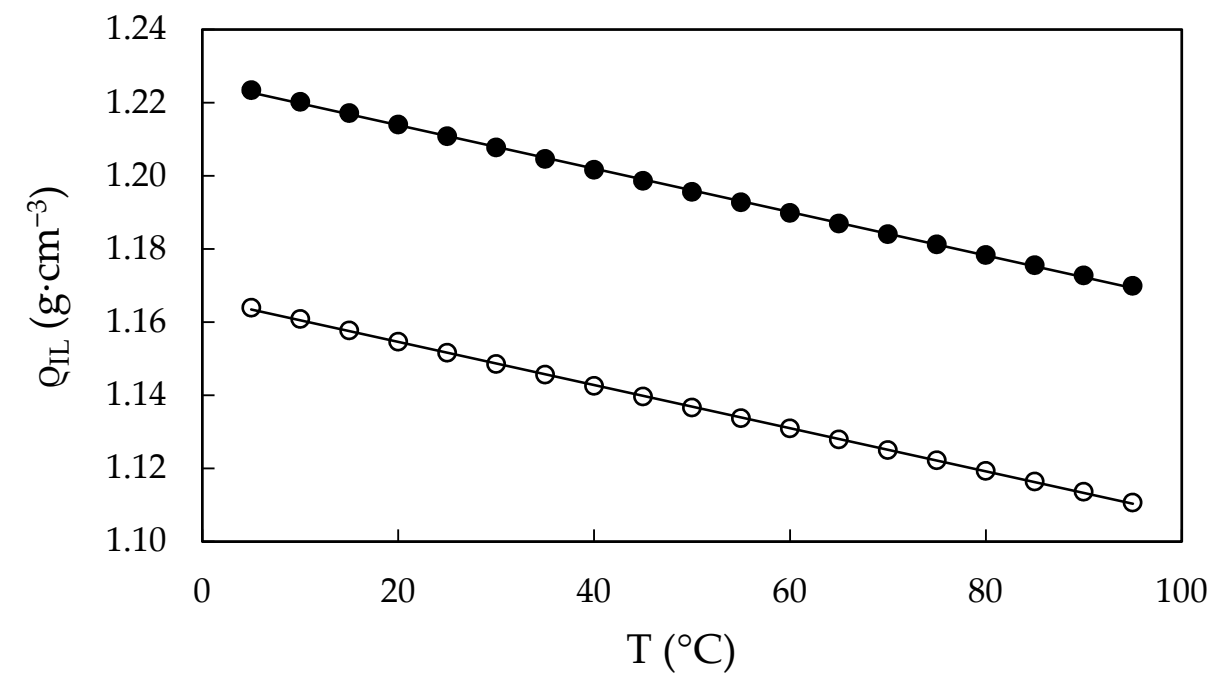

Figure 7. Calculated densities, $\rho_{\mathrm{IL}}$, of water-free EAN (solid dots) and PAN (open dots) as a function of the temperature, obtained from Equation (1). Solid line obtained from the best straight line.

The density data follow a linear trend with temperature as follows:

$$
\rho_{\mathrm{IL}}=\mathrm{A}_{\rho, 0}+\mathrm{A}_{\rho, 1} \mathrm{~T},
$$

where $\rho_{\mathrm{IL}}$ is the density of water-free $\mathrm{IL}, \mathrm{T}$ is the temperature in ${ }^{\circ} \mathrm{C}$ and $\mathrm{A}_{\rho, 0}$ and $\mathrm{A}_{\rho, 1}$ are the fitting parameters presented in Table 5 . These densities for both water-free ILs present a very similar slope, differing by $1.3 \%$.

In the case of viscosity and electrical conductivity, they can be correlated by the VogelTammann-Fulcher (VTF) equation, as is usual for liquids of this nature [91]. This equation can be generally written as:

$$
\mathrm{Q}_{\mathrm{IL}}=\mathrm{Q}_{\infty} \mathrm{e}^{\mathrm{B} /\left(\mathrm{T}+273,15-\mathrm{T}_{0}\right)},
$$

where $\mathrm{Q}_{\mathrm{IL}}$ describes $\eta_{\mathrm{IL}}$ or $\mathrm{K}_{\mathrm{IL}}, \mathrm{Q}_{\infty}$ is the limit of viscosity or electrical conductivity at infinite temperature, $B$ is related to the activation energy of ions to flow or to the activation energy for the ion hopping and, finally, $\mathrm{T}_{0}$ is related with the glass transition temperature in $\mathrm{K}[12,92-94]$ and $\mathrm{T}$ is the temperature expressed in ${ }^{\circ} \mathrm{C}$. The fitting parameters $\mathrm{Q}_{\infty}, \mathrm{B}$ 
and $\mathrm{T}_{0}$ are given in Table 5 , as well as the corresponding percentual deviation, which is defined as:

$$
\mathrm{s}=100 \sqrt{\frac{\sum_{\mathrm{i}=1}^{\mathrm{N}}\left(\frac{\mathrm{Q}_{\mathrm{IL}, \mathrm{i}}-\mathrm{Q}_{\mathrm{VTF}, \mathrm{i}}}{\mathrm{Q}_{\mathrm{IL}, \mathrm{i}}}\right)^{2}}{\mathrm{~N}-1}},
$$

where $\mathrm{QVTF}_{\mathrm{VT}}$ is the value of the calculated quantity obtained from the best fit of the VTF equation. The resulting curves are shown in Figure 8, showing a very good agreement with QIL data.

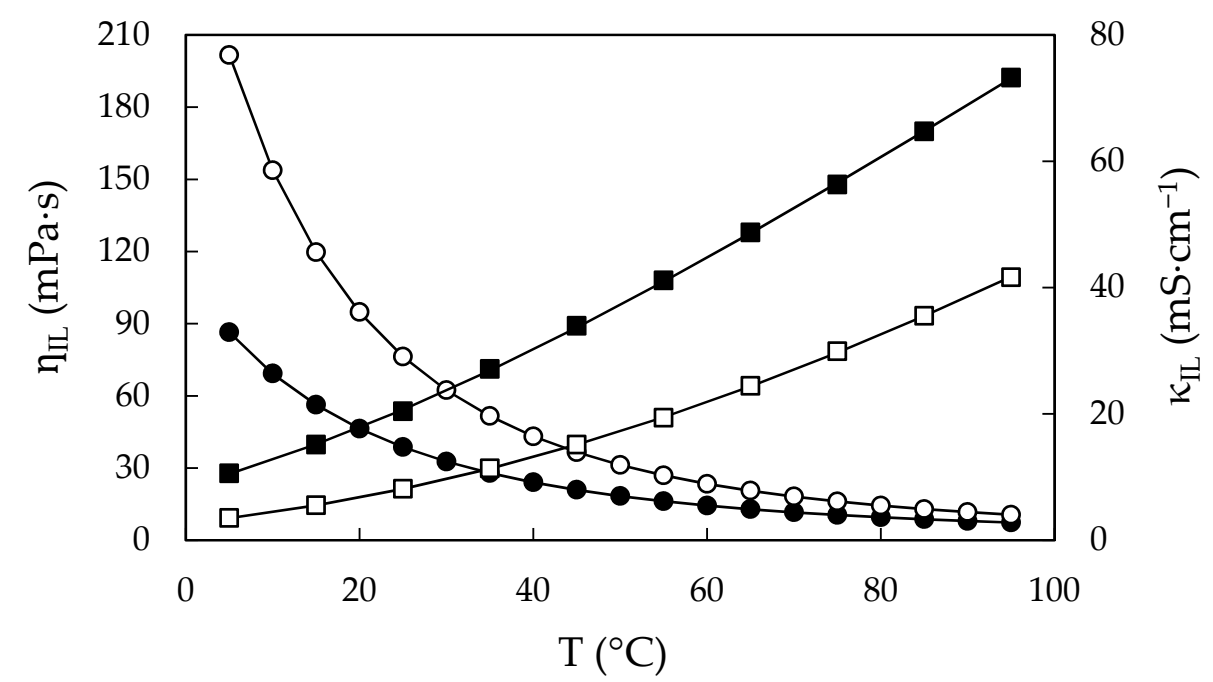

Figure 8. Calculated viscosities, $\eta_{\mathrm{IL}}$, and calculated electrical conductivities, $\mathrm{k}_{\mathrm{IL}}$, of water-free EAN (solid symbols) and PAN (open symbols) as a function of the temperature, obtained from Equation (1). Dots correspond to the left axis (viscosity) and squares to the right axis (electrical conductivity). Solid line obtained from VTF Equation (3).

Table 5. Fitting of density $\left(\mathrm{g} \cdot \mathrm{cm}^{-3}\right)$, viscosity $(\mathrm{mPa} \cdot \mathrm{s})$ and electrical conductivity $\left(\mathrm{mS} \cdot \mathrm{cm}^{-1}\right)$ data of water-free EAN and PAN as function of temperature: parameters of Equations (2) and (3), coefficient of determination $\mathrm{R}^{2}$ and percentual deviation (s).

\begin{tabular}{cccccccccccc}
\hline $\mathbf{I L}$ & $\mathbf{A}_{\boldsymbol{\rho}, \mathbf{0}}$ & $\mathbf{A}_{\boldsymbol{\rho}, \mathbf{1}} \mathbf{( 1 0}^{\mathbf{4}} \mathbf{)}$ & $\mathbf{R}^{\mathbf{2}} \boldsymbol{\rho}$ & $\mathbf{Q}_{\infty, \boldsymbol{\eta}}$ & $\mathbf{B}_{\boldsymbol{\eta}}$ & $\mathbf{T}_{\mathbf{0 , \boldsymbol { \eta }}}$ & $\mathbf{s}_{\boldsymbol{\eta}}$ & $\mathbf{Q}_{\infty, \boldsymbol{\kappa}}$ & $\mathbf{B}_{\boldsymbol{\kappa}}$ & $\mathbf{T}_{\mathbf{0 , \boldsymbol { \kappa }}}$ & $\mathbf{s}_{\boldsymbol{\kappa}}$ \\
\hline EAN & 1.2257 & -5.9379 & 0.9996 & 0.2111 & 778.8 & 148.7 & 0.06 & 666.2 & -424.9 & 175.8 & 0.7 \\
PAN & 1.1664 & -5.8998 & 0.9998 & 0.1823 & 869.5 & 154.1 & 0.10 & 904.1 & -620.8 & 166.4 & 0.3 \\
\hline
\end{tabular}

\subsection{Experimental Measurements as a Function of Water Content and Temperature}

The two properties most affected by the presence of water impurities can be expressed as a function of water content and temperature by means of a single equation. Thus, the fitting equation for the viscosity and electrical conductivity of the IL at a given water content and temperature is:

$$
\mathrm{Q}(\mathrm{w}, \mathrm{T})=\mathrm{Q}_{\mathrm{IL}}(\mathrm{T})+\sum_{\mathrm{i}=1}^{\mathrm{N}} \mathrm{A}_{\mathrm{Q}, \mathrm{i}}(\mathrm{T}) \mathrm{w}^{\mathrm{i}},
$$

where $Q(w, T)$ is $\eta(w, T)$ or $k(w, T), Q_{I L}(T)$ is the calculated water-free viscosity or electrical conductivity of the IL given by Equation (3) and the corresponding fitting parameters can be defined as:

$$
\begin{gathered}
A_{\eta, i}(T)=(-1)^{i} e^{\sum_{j=0}^{M} C_{j} j^{j}}, \\
A_{\kappa, i}(T)=\sum_{j=0}^{M} C_{j} T^{j},
\end{gathered}
$$


T being the temperature in ${ }^{\circ} \mathrm{C}$ in the 5 to $95{ }^{\circ} \mathrm{C}$ range. Finally, parameter $\mathrm{C}_{j}$ was the result of the best fit of parameter $A_{i}$ from Equation (1) and is reported in Table 6 together with the coefficients of determination $\mathrm{R}^{2}$.

Table 6. Fitting of viscosity ( $\mathrm{mPa} \cdot \mathrm{s})$ and electrical conductivity $\left(\mathrm{mS} \cdot \mathrm{cm}^{-1}\right)$ data of EAN and PAN as a function of water content and temperature: parameters of Equations (6) and (7) and coefficients of determination $\mathrm{R}^{2}$.

\begin{tabular}{|c|c|c|c|c|c|c|c|c|}
\hline \multirow{2}{*}{$\begin{array}{c}\text { IL } \\
\text { A (T) }\end{array}$} & \multicolumn{4}{|c|}{ EAN } & \multicolumn{4}{|c|}{ PAN } \\
\hline & $\mathrm{C}_{0}$ & $\mathrm{C}_{1}$ & $\mathrm{C}_{2}$ & $\mathbf{R}^{2}$ & $\mathrm{C}_{0}$ & $\mathrm{C}_{1}$ & $\mathrm{C}_{2}$ & $\mathbf{R}^{2}$ \\
\hline $\begin{array}{l}\mathrm{A}_{K}(\mathrm{~T}) \\
\mathrm{A}_{\eta, 1}(\mathrm{~T}) \\
\mathrm{A}_{\eta, 2}(\mathrm{~T})\end{array}$ & $\begin{array}{c}1.554 \times 10^{-4} \\
-6.246\end{array}$ & $\begin{array}{c}7.445 \times 10^{-6} \\
-4.994 \times 10^{-2}\end{array}$ & $\begin{array}{c}-1.549 \times 10^{-8} \\
1.740 \times 10^{-4}\end{array}$ & $\begin{array}{l}0.9954 \\
0.9997\end{array}$ & $\begin{array}{c}6.294 \times 10^{-5} \\
-4.917 \\
-16.22\end{array}$ & $\begin{array}{c}5.924 \times 10^{-6} \\
-5.883 \times 10^{-2} \\
-6.074 \times 10^{-2}\end{array}$ & $\begin{array}{c}-1.775 \times 10^{-8} \\
1.951 \times 10^{-4} \\
1.633 \times 10^{-4}\end{array}$ & $\begin{array}{l}0.9923 \\
0.9996 \\
0.9994\end{array}$ \\
\hline
\end{tabular}

The values obtained from Equation (5) show a very good agreement with experimental data for all water contents and temperatures studied, resulting in findings very similar to those calculated from Equations (1)-(3). Thus, the average percentual deviation for viscosities of EAN and PAN are 0.4 and 1.0, respectively, while those for electrical conductivities are 0.7 and 1.2 , respectively.

\subsection{Comparison with Published Data}

As mentioned in Introduction, an exhaustive review of the present state of the art in the densities, viscosities, electrical conductivities, refractive indexes and surface tension of EAN and PAN at different temperatures was performed. As a result, the published experimental physical properties here studied at $25^{\circ} \mathrm{C}$ are represented in Figures S1-S10 along with the properties measured in this work. On the other hand, Table S5 is also included in this section, which compiles in detail the properties studied in each bibliographic reference. From this review, it can be deduced that:

- Previously published data show a wide dispersion in all the properties studied;

- A significant number of papers do not present accurate information on the water content of pure ILs. In general, these data are the ones that differ the most from those presented here (open symbols in Figures S1-S10);

- Overall, those papers that do report on water content are in good agreement with those presented here;

- The data presented here provide systematic measurements and homogeneity, as well as covering previously unpublished temperature or water content ranges.

\section{Materials and Methods}

\subsection{Materials}

Ethylammonium nitrate (EAN) and propylammonium nitrate (PAN) are room temperature yellow to orange liquids that are commercially available. Both ILs were supplied by Iolitec and their mass fraction purity and percentage of water content certified by the supplier were $>0.97$ and $<2 \%$, respectively. To preserve the ILs from moisture, the bottles were sealed with film and handled in a chamber in which the relative humidity was maintained at $<15 \%$.

\subsection{Preparation of Materials}

The preparation of the samples started with a drying process which was different depending on their water content. For contents higher than 1000 ppm, the water removal was carried out under a reduced pressure of 10 mbar at a temperature of $120^{\circ} \mathrm{C}$ for 8 to $10 \mathrm{~h}$. Thereafter, the samples of IL were prepared by weight by adding the required amount of water to cover a range of concentrations up to $30,000 \mathrm{ppm}$. For water contents below $1000 \mathrm{ppm}$, the IL was exposed to pressures of $10^{-3} \mathrm{mbar}$ for $48 \mathrm{~h}$ and used without further modifications. At the end of both processes, the liquids were kept in a hermetically sealed flask with an internal argon atmosphere. 
The final water contents $(w)$ were determined using a Mettler Toledo coulometric Karl Fischer titrator $\mathrm{C} 10 \mathrm{~S}$, the estimated uncertainty of which is $50 \mathrm{ppm}$.

\subsection{Density and Viscosity}

Densities $(\rho)$ and viscosities $(\eta)$ were determined using an Anton Paar Stabinger VTM 3000 viscodensimeter with a repeatability of $0.5 \mathrm{~kg} \cdot \mathrm{m}^{-3}$ and $0.4 \%$ of the measured value for viscosity. The device has an internal Peltier thermostat presenting an uncertainty of $0.02{ }^{\circ} \mathrm{C}$ in temperature.

\subsection{Refractive Index}

Refractive indexes $\left(n_{D}\right)$ were measured with an Anton Paar Abbemat-WR automatic refractometer with an uncertainty of $4 \times 10^{-5}$. The device has an internal Peltier thermostat featuring an uncertainty of $0.03{ }^{\circ} \mathrm{C}$.

\subsection{Surface Tension}

Surface tensions $(\sigma)$ were determined using a Lauda TVT1 automated tensiometer, which presents an uncertainty of $0.02 \mathrm{mN} \cdot \mathrm{m}^{-1}$. A Lauda RC6 CP thermostatic bath controlled the temperature with an uncertainty $<0.2{ }^{\circ} \mathrm{C}$.

\subsection{Electrical Conductivity}

The electrical conductivity of the samples was measured by means of a Crison GLP 31 conductivity meter, which works with an alternating current of $500 \mathrm{~Hz}$ and a voltage of 4.5 V. The measuring cell Hach 5292 connected to it operates in a range from $0.2 \mu \mathrm{S} \cdot \mathrm{cm}^{-1}$ to $100 \mathrm{mS} \cdot \mathrm{cm}^{-1}$. It also allows a working temperature range from -30 to $80{ }^{\circ} \mathrm{C}$ with a repeatability of $0.5 \%$, it being possible to measure at higher temperatures as long as these are very stable. A Julabo F25 thermostatic bath controlled the temperature with an uncertainty of $0.1^{\circ} \mathrm{C}$.

\section{Conclusions}

This work contributes to an exhaustive physical characterization of EAN and PAN, two ILs widely used in many different fields of work. These are two hygroscopic liquids that require careful moisture control in their handling. In spite of the existence of a considerable number of articles published on their physical properties, it was found after a detailed bibliographic search that there is a great dispersion in the results obtained, and that in numerous cases, the water content of the pure materials was not provided.

In this work, several physical properties of EAN and PAN with water contents between 300 and 30,000 ppm were measured systematically. Thus, experimental densities, viscosities and electrical conductivity were reported for a wide range of temperatures between 5 and $95^{\circ} \mathrm{C}$, while the refractive index and surface tension were measured at $25^{\circ} \mathrm{C}$. As a result of this work, experimental measurements that have not previously been published over such a wide temperature range with a strict control of water content are provided.

The properties most significantly modified by the presence of water in EAN and PAN were those of transport. The calculated absolute value of the average percentage change from water-free to 30,000 ppm is between 39 and 56\%. Finally, a correlation equation dependent on both water content in the IL and temperature was provided for viscosity and electrical conductivity, resulting in a very good fit to all experimental data.

Supplementary Materials: The following are available online at https://www.mdpi.com/article/10 $.3390 / \mathrm{ijms} 22147334 / \mathrm{s} 1$. 
Author Contributions: Conceptualization, L.S. and O.C.; methodology, D.A., L.S. and O.C.; validation, D.A.; formal analysis, D.A. and L.S.; investigation, D.A. and J.J.P.; resources, O.C. and L.S.; data curation, D.A.; writing-original draft preparation, L.S.; writing-review and editing, L.S., D.A., O.C., L.M.V., J.J.P. and J.L.T.; visualization, D.A. and L.S.; supervision, L.S.; project administration, O.C., L.M.V. and L.S.; funding acquisition, O.C. and L.M.V. All authors have read and agreed to the published version of the manuscript.

Funding: This research was funded by the Spanish MINISTRY OF ECONOMY AND COMPETITIVENESS, grant numbers MAT2017-89239-C2-1-P and MAT2017-89239-C2-2-P. D. Ausín thanks the funding support of Fundación Segundo Gil Dávila. J.J. Parajó thanks the funding support of I2C postdoctoral program of Xunta de Galicia.

Institutional Review Board Statement: Not applicable.

Informed Consent Statement: Not applicable.

Data Availability Statement: Data is contained within the article or supplementary material.

Acknowledgments: The authors acknowledge the technical support given by Manuel Ramón Cabanas Vázquez.

Conflicts of Interest: The authors declare no conflict of interest.

\section{References}

1. Welton, T. Ionic liquids: A brief history. Biophys. Rev. 2018, 10, 691-706. [CrossRef] [PubMed]

2. Trujillo-Rodríguez, M.J.; Nan, H.; Varona, M.; Emaus, M.N.; Souza, I.D.; Anderson, J.L. Advances of Ionic Liquids in Analytical Chemistry. Anal. Chem. 2019, 91, 505-531. [CrossRef] [PubMed]

3. Keaveney, S.T.; Haines, R.S.; Harper, J.B. Ionic liquid solvents: The importance of microscopic interactions in predicting organic reaction outcomes. Pure Appl. Chem. 2017, 89, 745-757. [CrossRef]

4. Xia, S.-M.; Chen, K.-H.; Fu, H.-C.; He, L.-N. Ionic liquids catalysis for carbon dioxide conversion with nucleophiles. Front. Chem. 2018, 6, 462. [CrossRef] [PubMed]

5. Martins, V.L.; Torresi, R.M. Ionic liquids in electrochemical energy storage. Curr. Opin. Electrochem. 2018, 9, 26-32. [CrossRef]

6. Upasham, S.; Banga, I.K.; Jagannath, B.; Paul, A.; Lin, K.-C.; Muthukumar, S.; Prasad, S. Electrochemical impedimetric biosensors, featuring the use of Room Temperature Ionic Liquids (RTILs): Special focus on non-faradaic sensing. Biosens. Bioelectron. 2021, 177, 112940. [CrossRef] [PubMed]

7. Florio, W.; Becherini, S.; D'Andrea, F.; Lupetti, A.; Chiappe, C.; Guazzelli, L. Comparative evaluation of antimicrobial activity of different types of ionic liquids. Mater. Sci. Eng. C 2019, 104, 109907. [CrossRef]

8. Tampucci, S.; Guazzelli, L.; Burgalassi, S.; Carpi, S.; Chetoni, P.; Mezzetta, A.; Nieri, P.; Polini, B.; Pomelli, C.S.; Terreni, E.; et al. $\mathrm{pH}$-responsive nanostructures based on surface active fatty acid-protic ionic liquids for imiquimod delivery in skin cancer topical therapy. Pharmaceutics 2020, 12, 1078. [CrossRef]

9. Moodley, K.; Mabaso, M.; Bahadur, I.; Redhi, G.G. Industrial application of ionic liquids for the recoveries of spent paint solvent. J. Mol. Liq. 2016, 219, 206-210. [CrossRef]

10. Khan, A.S.; Ibrahim, T.H.; Jabbar, N.A.; Khamis, M.I.; Nancarrow, P.; Mjalli, F.S. Ionic liquids and deep eutectic solvents for the recovery of phenolic compounds: Effect of ionic liquids structure and process parameters. RSC Adv. 2021, 11, 12398. [CrossRef]

11. Lei, Z.; Chen, B.; Koo, Y.-M.; MacFarlane, D.R. Introduction: Ionic Liquids. Chem. Rev. 2017, 117, 6633-6635. [CrossRef]

12. Vila, J.; Gines, P.; Pico, J.M.; Franjo, C.; Jimenez, E.; Varela, L.M.; Cabeza, O. Temperature dependence of the electrical conductivity in EMIM-Based ionic liquids: Evidence of Vogel-Tamman-Fulcher behaviour. Fluid Phase Equilib. 2006, 242, 141-146. [CrossRef]

13. Rilo, E.; Dominguez-Perez, M.; Vila, J.; Segade, L.; Garcia, M.; Varela, L.M.; Cabeza, O. Easy prediction of the refractive index for binary mixtures of ionic liquids with water or ethanol. J. Chem. Thermodyn. 2012, 47, 219-222. [CrossRef]

14. Cabeza, O.; Varela, L.M.; Rilo, E.; Segade, L.; Dominguez-Perez, M.; Ausin, D.; de Pedro, I.; Rodriguez Fernandez, J.; Gonzalez, J.; Vazquez-Tato, M.P.; et al. Synthesis, microstructure and volumetry of novel metal thiocyanate ionic liquids with [BMIM] cation. J. Mol. Liq. 2019, 283, 638-651. [CrossRef]

15. Segade, L.; Cabanas, M.; Domínguez-Pérez, M.; Rilo, E.; García-Garabal, S.; Turmine, M.; Varela, L.M.; Gómez-González, V.; Docampo-Álvarez, B.; Cabeza, O. Surface and bulk characterisation of mixtures containing alkylammonium nitrates and water or ethanol: Experimental and simulated properties at 298.15 K. J. Mol. Liq. 2016, 222, 663-670. [CrossRef]

16. Salgado, J.; Parajó, J.J.; Villanueva, M.; Rodríguez, J.R.; Cabeza, O.; Varela, L.M. Liquid range of ionic liquid-Metal salt mixtures for electrochemical applications. J. Chem. Thermodyn. 2019, 134, 164-174. [CrossRef]

17. Greaves, T.L.; Drummond, C.J. Protic Ionic Liquids: Properties and Applications. Chem. Rev. 2008, 108, 206-237. [CrossRef]

18. Greaves, T.L.; Drummond, C.J. Protic Ionic Liquids: Evolving Structure-Property Relationships and Expanding Applications. Chem. Rev. 2015, 115, 11379-11448. [CrossRef] 
19. Bhattacharya, K.; Sarkar, M.; Salez, T.J.; Nakamae, S.; Demouchy, G.; Cousin, F.; Dubois, E.; Michot, L.; Perzynski, R.; Peyre, V. Structural, Thermodiffusive and Thermoelectric Properties of Maghemite Nanoparticles Dispersed in Ethylammonium Nitrate. Chem. Eng. 2020, 4, 5. [CrossRef]

20. Pajak, M.; Hubkowska, K.; Czerwinski, A. Nitrate protic ionic liquids as electrolytes: Towards hydrogen sorption in Pd. Electrochim. Acta 2019, 324, 134851. [CrossRef]

21. Laux, E.; Jeandupeux, L.; Uhl, S.; Keppner, H.; Perez Lopez, P.; Sanglard, P.; Vanoli, E.; Marti, R. Novel Ionic Liquids for Thermoelectric Generator Devices. Mater. Today Proc. 2019, 8, 672-679. [CrossRef]

22. Yoshida, K.; Zenin, T.; Fujiyoshi, A.; Sanada, Y.; Yamaguchi, T.; Murata, K.; Takata, S.-I.; Hiroi, K.; Takekiyo, T.; Yoshimura, Y. The effect of alkyl ammonium ionic liquids on thermal denaturation aggregation of $\beta$-lactoglobulin. J. Mol. Liq. 2019, 293, 111477. [CrossRef]

23. Allen, M.; Evans, D.F.; Lumry, R. Thermodynamic properties of the ethylammonium nitrate + water system: Partial molar volumes, heat capacities, and expansivities. J. Sol. Chem. 1985, 14, 549-560. [CrossRef]

24. Anaredy, R.S.; Lucio, A.J.; Shaw, S.K. Adventitious Water Sorption in a Hydrophilic and a Hydrophobic Ionic Liquid: Analysis and Implications. ACS Omega 2016, 1, 407-416. [CrossRef]

25. Angell, C.A.; Xu, W.; Belieres, J.; Yoshizawa, M. Ionic Liquids and Ionic Liquid Acids with High Temperature Stability for Fuel Cell and Other High Temperature Applications, Method of Making and Cell Employing Same. US Patent US 7,867,658 B2; filed 3 May 2004 and issued 11 January 2011.

26. Anouti, M.; Caillon-Caravanier, M.; Dridi, Y.; Galiano, H.; Lemordant, D. Synthesis and Characterization of New Pyrrolidinium Based Protic Ionic Liquids. Good and Superionic Liquids. J. Phys. Chem. B 2008, 112, 13335-13343. [CrossRef]

27. Atkin, R.; Warr, G.G. Structure in Confined Room-Temperature Ionic Liquids. J. Phys. Chem. C 2007, 111, 5162-5168. [CrossRef]

28. Atkin, R.; Warr, G.G. The Smallest Amphiphiles: Nanostructure in Protic Room-Temperature Ionic Liquids with Short Alkyl Groups. J. Phys. Chem. B 2008, 112, 4164-4166. [CrossRef]

29. Atkin, R.; Warr, G.G. Bulk and Interfacial Nanostructure in Protic Room Temperature Ionic Liquids. In Ionic Liquids: From Knowledge to Application; ACS Symposium, Series; Plechkova, N.V., Rogers, R.D., Seddon, K.R., Eds.; American Chemical Society: Washington, DC, USA, 2009; Volume 1030, pp. 317-333.

30. Barycki, M.; Sosnowska, A.; Gajewicz, A.; Bobrowski, M.; Wileńska, D.; Skurski, P.; Gieldoń, A.; Czaplewski, C.; Uhl, S.; Laux, E.; et al. Temperature-dependent structure-property modeling of viscosity for ionic liquids. Fluid Phase Equilib. 2016, 427, 9-17. [CrossRef]

31. Belieres, J.; Gervasio, D.; Angell, A. Binary inorganic salt mixtures as high conductivity liquid electrolytes for $>100{ }^{\circ} \mathrm{C}$ fuel cells. Chem. Commun. 2006, 14, 4799-4801. [CrossRef]

32. Benhlima, N.; Turmine, M.; Letellier, P.; Naejus, R.; Lemordant, D. Étude électrochimique du nitrate d'éthylammonium fondu à 298 K: Établissement d'une echelle de potentiel redox. J. Chim. Phys. 1998, 95, 25-44. [CrossRef]

33. Berthod, A.; Ruiz-Ángel, M.J.; Carda-Broch, S. lonic liquids in separation techniques. J. Chromatogr. A 2008, 1184, 6-18. [CrossRef]

34. Bonetti, M.; Oleinikova, A.; Bervillier, C. Coexistence Curve of the Ionic Binary Mixture Ethylammonium Nitrate-n-Octanol: Critical Properties. J. Phys. Chem. B 1997, 101, 2164-2173. [CrossRef]

35. Campetella, M.; Mariani, A.; Sadun, C.; Wu, E.; Castner, E.W.; Gontrani, L. Structure and dynamics of propylammonium nitrate-acetonitrile mixtures: An intricate multi-scale system probed with experimental and theoretical techniques. J. Chem. Phys. 2018, 148, 134507. [CrossRef]

36. Canongia Lopes, J.N.; Esperança, J.M.S.S.; Mão de Ferro, A.; Pereiro, A.B.; Plechkova, N.V.; Rebelo, L.P.N.; Seddon, K.R.; Vázquez-Fernández, I. Protonic Ammonium Nitrate Ionic Liquids and Their Mixtures: Insights into Their Thermophysical Behavior. J. Phys. Chem. B 2016, 120, 2397-2406. [CrossRef]

37. Capelo, S.B.; Méndez-Morales, T.; Carrete, J.; López Lago, E.; Vila, J.; Cabeza, O.; Rodríguez, J.R.; Turmine, M.; Varela, L.M. Effect of Temperature and Cationic Chain Length on the Physical Properties of Ammonium Nitrate-Based Protic Ionic Liquids. J. Phys. Chem. B 2012, 116, 11302-11312. [CrossRef]

38. Chagnes, A.; Tougui, A.; Carré, B.; Ranganathan, N.; Lemordant, D. Abnormal Temperature Dependence of the Viscosity of Ethylammonium Nitrate-Methanol Ionic Mixtures. J. Solut. Chem. 2004, 33, 247-255. [CrossRef]

39. Evans, D.F.; Yamauchi, A.; Roman, R.; Casassa, E.Z. Micelle Formation in Ethylammonium Nitrate, a Low-Melting Fused Salt. J. Colloid Interface Sci. 1982, 88, 89-96. [CrossRef]

40. Evans, D.F.; Yamauchi, A.; Wei, G.J.; Bloomfleid, V.A. Micelle Size in Ethylammonium Nitrate As Determined by Classical and Quasi-Elastic Light Scattering. J. Phys. Chem. 1983, 87, 3537-3541. [CrossRef]

41. Frost, D.S.; Ngan, M.; Dai, L.L. Spontaneous Transport of Microparticles across Liquid-Liquid Interfaces. Langmuir 2013, 29, 9310-9315. [CrossRef]

42. Frost, D.S.; Machas, M.; Perea, B.; Dai, L.L. Nonconvective Mixing of Miscible Ionic Liquids. Langmuir 2013, 29, 10159-10165. [CrossRef]

43. Greaves, T.L.; Weerawardena, A.; Fong, C.; Krodkiewska, I.; Drummond, C.J. Protic Ionic Liquids: Solvents with Tunable Phase Behavior and Physicochemical Properties. J. Phys. Chem. B 2006, 110, 22479-22487. [CrossRef]

44. Greaves, T.L.; Weerawardena, A.; Fong, C.; Drummond, C.J. Formation of Amphiphile Self-Assembly Phases in Protic Ionic Liquids. J. Phys. Chem. B 2007, 111, 4082-4088. [CrossRef] 
45. Greaves, T.L.; Mudie, S.T.; Drummond, C.J. Effect of protic ionic liquids (PILs) on the formation of non-ionic dodecyl poly(ethylene oxide) surfactant self-assembly structures and the effect of these surfactants on the nanostructure of PILs. Phys. Chem. Chem. Phys. 2011, 13, 20441-20452. [CrossRef]

46. Hadded, M.; Biquard, M.; Letellier, P.; Schaal, R. Proprietes volumiques du nitrate d'ethylammonium fondu a $298 \mathrm{~K}$ et de ses melanges avec l'eau. Can. J. Chem. 1985, 63, 565-570. [CrossRef]

47. Hadded, M.; Bahri, H.; Letellier, P. Tensions superficielles des mélanges binaires EAU-Nitrate d'éthylammonium à 298 K. J. Chim. Phys. 1986, 83, 419-426. [CrossRef]

48. Hadded, M.; Mayaffre, A.; Letellier, P. Tensions superficielles des solutions idéales: Application aux solvants binaires constitués de methanol et de nitrate d'ethylammonium fondu a 298 K. J. Chim. Phys. 1989, 86, 525-537. [CrossRef]

49. Hjalmarsson, N.; Atkin, R.; Rutland, M.W. Effect of Lithium Ions on Rheology and Interfacial Forces in Ethylammonium Nitrate and Ethanolammonium Nitrate. J. Phys. Chem. C 2016, 120, 26960-26967. [CrossRef]

50. Hjalmarsson, N.; Atkin, R.; Rutland, M.W. Is the boundary layer of an ionic liquid equally lubricating at higher temperature? Phys. Chem. Chem. Phys. 2016, 18, 9232-9239. [CrossRef]

51. Kaneko, K.; Yoshimura, Y.; Shimizu, A. Water concentration dependence of the refractive index of various ionic liquid-water mixtures. J. Mol. Liq. 2018, 250, 283-286. [CrossRef]

52. Kanzaki, R.; Uchida, K.; Song, X.; Umebayashi, Y.; Ishiguro, S. Acidity and Basicity of Aqueous Mixtures of a Protic Ionic Liquid, Ethylammonium Nitrate. Anal. Sci. 2008, 24, 1347-1349. [CrossRef]

53. Krueger, M.; Bründermann, E.; Funkner, S.; Weingärtner, H.; Havenith, M. Communications: Polarity fluctuations of the protic ionic liquid ethylammonium nitrate in the terahertz regime. J. Chem. Phys. 2010, 132, 101101. [CrossRef]

54. Kundu, N.; Roy, A.; Dutta, R.; Sarkar, N. Translational and Rotational Diffusion of Two Differently Charged Solutes in Ethylammonium Nitrate-Methanol Mixture: Does the Nanostructure of the Amphiphiles Influence the Motion of the Solute? J. Phys. Chem. B 2016, 120, 5481-5490. [CrossRef]

55. López-Barrón, C.R.; Wagner, N.J. Structural Transitions of CTAB Micelles in a Protic Ionic Liquid. Langmuir 2012, 28, 12722-12730. [CrossRef]

56. Malham, I.B.; Letellier, P.; Mayaffre, A.; Turmine, M. Part I: Thermodynamic analysis of volumetric properties of concentrated aqueous solutions of 1-butyl-3-methylimidazolium tetrafluoro borate, 1-butyl-2,3-dimethylimidazolium tetrafluoroborate, and ethylammonium nitrate based on pseudo-lattice theory. J. Chem. Thermodyn. 2007, 39, 1132-1143. [CrossRef]

57. Mariani, A.; Russina, O.; Caminiti, R.; Triolo, A. Structural organization in a methanol:ethylammonium nitrate (1:4) mixture: A joint X-ray/Neutron diffraction and computational study. J. Mol. Liq. 2015, 212, 947-956. [CrossRef]

58. Mariani, A.; Caminiti, R.; Ramondo, F.; Salvitti, G.; Mocci, F.; Gontrani, L. Inhomogeneity in Ethylammonium Nitrate-Acetonitrile Binary Mixtures: The Highest “Low q Excess” Reported to Date. J. Phys. Chem. Lett. 2017, 8, 3512-3522. [CrossRef]

59. Mariani, A.; Bonomo, M.; Wu, B.; Centrella, B.; Dini, D.; Castner, E.W., Jr.; Gontrani, L. Intriguing transport dynamics of ethylammonium nitrate-acetonitrile binary mixtures arising from nano-inhomogeneity. Phys. Chem. Chem. Phys. 2017, 19, 27212-27220. [CrossRef]

60. Méndez-Morales, T.; Carrete, J.; Cabeza, O.; Russina, O.; Triolo, A.; Gallego, L.J.; Varela, L.M. Solvation of Lithium Salts in Protic Ionic Liquids: A Molecular Dynamics Study. J. Phys. Chem. B 2014, 118, 761-770. [CrossRef] [PubMed]

61. Moore, L.J.; Summers, M.D.; Ritchie, A.D. Optical trapping and spectroscopic characterisation of ionic liquid solutions. Phys. Chem. Chem. Phys. 2013, 15, 13489-13498. [CrossRef] [PubMed]

62. Oleinikova, A.; Bonetti, M. Critical Behavior of the Electrical Conductivity of Concentrated Electrolytes: Ethylammonium Nitrate in n-Octanol Binary Mixture. J. Sol. Chem. 2002, 31, 397-413. [CrossRef]

63. Perlt, E.; Ray, P.; Hansen, A.; Malberg, F.; Grimme, S.; Kirchner, B. Finding the best density functional approximation to describe interaction energies and structures of ionic liquids in molecular dynamics studies. J. Chem. Phys. 2018, 148, 193835. [CrossRef]

64. Perron, G.; Hardy, A.; Justice, J.-C.; Desnoyers, J.E. Model System for Concentrated Electrolyte Solutions: Thermodynamic and Transport Properties of Ethylammonium Nitrate in Acetonitrile and in Water. J. Sol. Chem. 1993, 22, 1159-1178. [CrossRef]

65. Poole, C.F.; Kersten, B.R.; Ho, S.S.; Coddens, M.E.; Furton, K.G. Organic Salts, Liquid at Room Temperature, as Mobile Phases in Liquid Chromatography. J. Chromatogr. A 1986, 352, 407-425. [CrossRef]

66. Poole, C.F. Chromatographic and spectroscopic 1nethods $\mathrm{f}$ or the determination of solvent properties of room temperature ionic liquids. J. Chromatogr. A 2004, 1037, 49-82. [CrossRef] [PubMed]

67. Porcedda, S.; Marongiu, B.; Schirru, M.; Falconieri, D.; Piras, A. Excess enthalpy and excess volume for binary systems of two ionic liquids + water. J. Therm. Anal. Calorim. 2011, 103, 29-33. [CrossRef]

68. Prabhu, S.R.; Dutt, G.B. Does Addition of an Electrolyte Influence the Rotational Diffusion of Nondipolar Solutes in a Protic Ionic Liquid? J. Phys. Chem. B 2015, 119, 6311-6316. [CrossRef] [PubMed]

69. Ridings, C.; Warr, G.G.; Andersson, G.G. Surface Ordering in Binary Mixtures of Protic Ionic Liquids. J. Phys. Chem. Lett. 2017, 8 , 4264-4267. [CrossRef]

70. Russina, O.; Mariani, A.; Caminiti, R.; Triolo, A. Structure of a Binary Mixture of Ethylammonium Nitrate and Methanol. J. Sol. Chem. 2015, 44, 669-685. [CrossRef]

71. Shetty, P.H.; Youngberg, P.J.; Kersen, B.R.; Poole, C.F. Solvent properties of liquid organic salts used as mobile phases in microcolumn reversed-phase liquid chromatography. J. Chromatogr. A 1987, 411, 61-79. [CrossRef] 
72. Shotwell, J.B.; Flowers II, R.A. Electrochemical Investigation of the Solvolytic Properties of Ethylammonium Nitrate (EAN) and Propylammonium Nitrate (PAN). Electroanalysis 2000, 12, 223-226. [CrossRef]

73. Smith, J.A.; Webber, G.B.; Warr, G.G.; Atkin, R. Rheology of Protic Ionic Liquids and Their Mixtures. J. Phys. Chem. B 2013, 117, 13930-13935. [CrossRef]

74. Smith, J.A.; Webber, G.B.; Warr, G.G.; Zimmer, A.; Atkin, R.; Werzer, O. Shear dependent viscosity of poly( ethylene oxide) in two protic ionic liquids. J. Colloid Interface Sci. 2014, 430, 56-60. [CrossRef]

75. Song, X.; Hamano, H.; Minofar, B.; Kanzaki, R.; Fujii, K.; Kameda, Y.; Kohara, S.; Watanabe, M.; Ishiguro, S.; Umebayashi, Y. Structural Heterogeneity and Unique Distorted Hydrogen Bonding in Primary Ammonium Nitrate Ionic Liquids Studied by High-Energy X-ray Diffraction Experiments and MD Simulations. J. Phys. Chem. B 2012, 116, 2801-2813. [CrossRef]

76. Sonnleitner, T.; Nikitina, V.; Nazet, A.; Buchner, R. Do H-bonds explain strong ion aggregation in ethylammonium nitrate + acetonitrile mixtures? Phys. Chem. Chem. Phys. 2013, 15, 18445-18452. [CrossRef]

77. Sonnleitner, T.; Turton, D.A.; Hefter, G.; Ortner, A.; Waselikowski, S.; Walther, M.; Wynne, K.; Buchner, R. Ultra-Broadband Dielectric and Optical Kerr-Effect Study of the Ionic Liquids Ethyl and Propylammonium Nitrate. J. Phys. Chem. B 2015, 119, 8826-8841. [CrossRef]

78. Sugden, S.; Wilkins, H. CLXVII.-The parachor and chemical constitution. Part XII. Fused metals and salts. J. Chem. Soc. 1929, 1291-1298. [CrossRef]

79. Thater, J.C.; Gérard, V.; Stubenrauch, C. Microemulsions with the Ionic Liquid Ethylammonium Nitrate: Phase Behavior, Composition, and Microstructure. Langmuir 2014, 30, 8283-8289. [CrossRef]

80. Turton, D.A.; Sonnleitner, T.; Ortner, A.; Walther, M.; Hefter, G.; Seddon, K.R.; Stana, S.; Plechkova, N.V.; Buchner, R.; Wynne, K. Structure and dynamics in protic ionic liquids: A combined optical Kerr-effect and dielectric relaxation spectroscopy study. Faraday Discuss. 2012, 154, 145-153. [CrossRef] [PubMed]

81. Usula, M.; Matteoli, E.; Leonelli, F.; Mocci, F.; Marincola, F.C.; Gontrani, L.; Porcedda, S. Thermo-physical properties of ammonium-based ionic liquid + N-methyl-2-pyrrolidone mixtures at 298.15 K. Fluid Phase Equilib. 2014, 383, 49-54. [CrossRef]

82. Wakeham, D.; Nelson, A.; Warr, G.G.; Atkin, R. Probing the protic ionic liquid surface using X-ray reflectivity. Phys. Chem. Chem. Phys. 2011, 13, 20828-20835. [CrossRef] [PubMed]

83. Wakeham, D.; Eschebach, D.; Webber, G.B.; Atkin, R.; Warr, G.G. Surface Composition of Mixtures of Ethylammonium Nitrate, Ethanolammonium Nitrate, and Water. Aust. J. Chem. 2012, 65, 1554-1556. [CrossRef]

84. Weingärtner, H.; Merkel, T.; Käshammer, S.; Schröer, W.; Wiegand, S. The Effect of Short-Range Hydrogen-Bonded Interactions on the Nature of the Critical Point of Ionic Fluids. Part I: General Properties of the New System Ethylammonium Nitrate+n-Octanol with an Upper Consolute Point Near Room Temperature. Ber. Bunsenges. Phys. Chem. 1993, 97, 970-975. [CrossRef]

85. Weingärtner, H.; Knocks, A.; Schrader, W.; Kaatze, U. Dielectric Spectroscopy of the Room Temperature Molten Salt Ethylammonium Nitrate. J. Phys. Chem. A 2001, 105, 8646-8650. [CrossRef]

86. Yalcin, D.; Drummond, C.J.; Greaves, T.L. High throughput approach to investigating ternary solvents of aqueous nonstoichiometric protic ionic liquids. Phys. Chem. Chem. Phys. 2019, 21, 6810-6827. [CrossRef]

87. Zarrougui, R.; Dhahbi, M.; Lemordant, D. Volumetric Properties of Ethylammonium Nitrate $+\gamma$-Butyrolactone Binary Systems: Solvation Phenomena from Density and Raman Spectroscopy. J. Sol. Chem. 2010, 39, 1531-1548. [CrossRef]

88. Zarrougui, R.; Dhahbi, M.; Lemordan, D. Electrochemical behaviour of iodine redox couples in aprotic and protic RTILs: 1-Butyl1-methylpyrrolidinium bis( trifluoromethanesulfonyl)imide and ethylammonium nitrate. J. Electroanal. Chem. 2014, 717-718, 189-195. [CrossRef]

89. Zarrougui, R.; Dhahbi, M.; Lemordant, D. Transport and Thermodynamic Properties of Ethylammonium Nitrate-Water Binary Mixtures: Effect of Temperature and Composition. J. Sol. Chem. 2015, 44, 686-702. [CrossRef]

90. Cuadrado-Prado, S.; Domínguez-Pérez, M.; Rilo, E.; García-Garabal, S.; Segade, L.; Franjo, C.; Cabeza, O. Experimental measurement of the hygroscopic grade on eight imidazolium based ionic liquids. Fluid Phase Equilib. 2009, 278, 36-40. [CrossRef]

91. Cabeza, O.; García-Garabal, S.; Segade, L.; Domínguez-Pérez, M.; Rilo, E.; Varela, L.M. Physical Properties of Binary Mixtures of ILs with Water and Ethanol. A Review. In Ionic Liquids: Theory, Properties, New Approaches; Kokorin, A., Ed.; InTech: Rijeka, Croatia, 2011; pp. 111-136. Available online: https://www.intechopen.com/books/ionic-liquids-theory-properties-new-approaches/ physical-properties-of-binary-mixtures-of-ils-with-water-and-ethanol-a-review- (accessed on 6 July 2021).

92. Vogel, H. The law of the relationship between viscosity of liquids and the temperature. Phys. Z. 1921, 22, 645-646.

93. Tammam, G.; Hesse, W. Die Abhängigkeit der viskosität von der temperatur bie unterkühlten flüssigkeiten. Z. Anorg. Allg. Chem. 1926, 156, 245-257. [CrossRef]

94. Fulcher, G.S. Analysis of recent measurements of the viscosity of glasses. J. Am. Ceram. Soc. 1952, 8, 339-360. [CrossRef] 